\title{
Investigation of Stock Market Integration in the Baltic Countries
}

\author{
Vilma Deltuvaitė \\ Kaunas University of Technology
}

\begin{abstract}
Recent rapid development of the Baltic stock markets raises the question about stock market integration level in these countries. Some empirical aspects of the Baltic stock market integration have been analysed in the scientific literature, however, a comprehensive analysis on the Baltic stock market integration level is still missing. The aim of the paper is to assess the regional integration level of the Baltic stock markets. The research object is stock markets in the Baltic countries. The following research and statistical methods have been applied in this study: the systemic and comparative analysis of the scientific literature, Spearman's correlation coefficient, dynamic conditional correlation generalized autoregressive conditional heteroskedasticity model, Granger causality test, generalized impulse response analysis, Johansen cointegration test, autoregressive distributed lag model and error correction model. The main findings of this empirical study are (a) all three Baltic stock markets are closely related markets, (b) however, the Latvian stock market is more isolated at the regional level comparing to other two Baltic stock markets (c) whereas Estonian and Lithuanian stock markets are more interrelated.
\end{abstract}

Keywords - Baltic countries, integration, stock market.

\section{INTRODUCTION}

While interdependence between the stock markets has been always a very important issue in financial economics, recent developments in the Baltic stock markets rise the question about the stock market integration level in these countries. The Baltic stock markets have seen rapid development during the past decade. The development of the Baltic stock markets has been influenced by a variety of factors: macroeconomic developments, political and legal systems, privatisation of state owned companies, introduction of a single trading platform in all seven Nordic and Baltic stock markets and a single trading and clearing currency (euro) in all three Baltic countries in 2010, etc. A single Baltic stock market trading infrastructure has increased stock market technical integration in these countries; however, technical integration of stock markets not always implies higher equity market integration in terms of returns and volatilities.

Some academics have analysed the Baltic stock market integration at the global and regional level. Pajuste et al. (2000), Mateus (2004), Cajueiro \& Tabak (2006), Syllignakis \& Kouretas (2011) analysed a range of risk indicators that could potentially influence return changes in stock markets of the Central and Eastern European countries (CEEC). The results of these empirical studies suggest that international risk drivers are statistically significant for Estonia and Lithuania, while domestic risk drivers - for Latvia. Despite the fact that the Baltic stock markets are vulnerable to external shocks, Lithuania and Estonia are low interrelated to global stock markets. Maneschiöld (2006), Nielsson (2007), Nikkinen et al. (2012) investigated the linkages between Nordic, Baltic stock and major global stock markets. The results of these studies show low integration between global and the Bal- tic stock markets; however, the global integration of Baltic stock markets has increased during the recent global financial crisis. Soultanaeva (2008), Dubinskas \& Stunguriene (2010), Masood et al. (2010), Brännäs \& Soultanaeva (2011), Brännäs et al. (2012) focused on stock exchanges of the Baltic States and the influence exerted by the Russian stock exchange. The overall findings of these empirical studies suggest that only a weak relationship between the Baltic stock market volatility and political risk factors exists. However, the authors have found strong evidence that the Baltic stock markets are co-integrated and feedback effect between analysed stock markets exists. They also found that a bidirectional relationship between Baltic stock indices exists. To sum up, most scientists analysing stock market integration in the Baltic countries focus on the short-run relationship among these stock markets, whereas a comprehensive analysis on the Baltic stock market integration level is still missing. This empirical study focuses on the investigation of stock market integration in the Baltic countries and comprehensive analysis of long-run and short-run causality among Baltic stock markets.

The aim of the article is to assess the regional integration level of the Baltic stock markets. The research object is stock markets in the Baltic countries. The following research and statistical methods have been applied in this study: the systemic and comparative analysis of the scientific literature, Spearman's correlation coefficient, dynamic conditional correlation generalized autoregressive conditional heteroskedasticity model (DCCGARCH), Granger causality test, generalized impulse response (GIR) analysis, Johansen cointegration test, autoregressive distributed lag (ARDL) model and error correction model (ECM).

II. The Review of Studies Analysing Stock Market InTEGRATION IN THE Baltic Countries

Recent developments in the Baltic stock markets raise the question about the Baltic stock markets integration level. Some scientists have analysed the Baltic stock market integration at the global and regional level. Pajuste et al. (2000) analysed a range of risk indicators that could potentially influence return changes in five CEEC stock markets. The results show that domestic factors are the most important in Slovenia, the Czech Republic, and Poland, while the risk factors related to emerging stock markets are the most important in Estonia and Hungary. Mateus (2004) analysed the relevance of global risk factors for returns of the 13 European Union (EU) accession countries during the period of 1997-2002. The results of this study show that global risk factors are relatively more important for 8 countries, including Estonia, Bulgaria, Romania, Cyprus, Lithuania, and Hungary, while local risk factors for Poland, the Czech Republic, Latvia, and Slovenia. Cajueiro and Tabak (2006) provided substantial empirical evi- 
dence of long-run and short-run predictability of stock returns of transition European economies (the Czech Republic, Bulgaria, Estonia, Croatia, Hungary, Poland, Latvia, Ukraine, and Russia). They tested for short-run predictability of stock returns that had been found in most sample countries. The authors also tested for long-run dependence between stock returns that had also been confirmed in all sample countries. Furthermore, they found substantial empirical evidence of strong time-varying long-run dependence in stock returns of these countries confirming the multifractality of equity returns. Maneschiöld (2006) investigated the long-run interdependence among major global stock markets (Germany, the United States, the United Kingdom, Japan, and France) and the Baltic stock markets. In general, the results indicate a low degree of global integration of the Baltic capital markets and short-term Granger causality running from the European markets to the Baltic markets. Nielsson (2007) analysed the relations of the Baltic and Nordic stock markets over the sample period of 1996-2006. The empirical results show a very little interrelation between the Baltic and Nordic stock indices. Soultanaeva (2008) analysed the relation between political events and news, the volatilities and returns in the Baltic stock markets. In general, there is only a weak relationship between political news and the Baltic stock market volatility. Dubinskas and Stunguriene (2010) analysed the alternations in the causality in Russia and the Baltic States financial markets in the period of 2008-2009. The results show a strong cointegration between all equity markets irrespective of the period analysed. Masood et al. (2010) investigated the cointegration and causal relationship between the Baltic countries. The authors have found strong evidence that the stock markets are co-integrated and feedback effect between analysed stock markets exists. They also have found that a long-run bidirectional causal relationship between the Baltic stock markets exists. Syllignakis and Kouretas (2011) examined the time-varying conditional correlations of 7 CEEC stock markets for the period of 1997-2009. The main findings are that there is a statistically significant increase in interdependence between the CEECs, US and the German stock markets, particularly during 2007-2009. Kuusk et al. (2011) investigated the spillover effect from the USA to the Baltic States during the recent financial crisis. The results show that stock returns' correlations between the USA and Baltic States increased during this crisis; however, volatility spillovers did not become stronger after the financial crisis hit. Brännäs and Soultanaeva (2011) studied the impact of news from Russia and the US on the Baltic stock market returns and volatilities. The results show that news from the US has stronger effects on returns in Tallinn while Vilnius is more affected by shocks from Russia. Nikkinen et al. (2012) analysed the linkages between the European and Baltic stock markets. The empirical results suggest the increased integration of the Baltic stock markets during this financial crisis. Brännäs et al. (2012) studied the three closely related stock exchanges of the Baltic States and the influence exerted by the Russian stock exchange. The authors found the integration of the Baltic stock markets to be substantial in terms of returns and volatility. As far as returns are concerned, Riga stock market is dependent on Tallinn and Vilnius stock exchanges, Tallinn stock exchange on Vilnius, while Vilnius is not affected by the other two stock markets. In terms of volatility, they found within a day spillovers from Tallinn to both Riga and Vilnius. In addition, they also found asymmetric effects of Moscow returns on the index returns in the Baltic stock exchanges, and asymmetric effects of Moscow risk on volatilities.

To sum up, the main conclusions can be formulated: (1) the degree of international integration of the Baltic stock markets is very low; (2) whereas, the regional integration of the Baltic stock markets is high; (3) despite the low international integration the spillover effect from the major stock markets is observed on the Baltic stock markets.

III. InVESTIGATION OF STOCK MARKET InTEgRATION in the Baltic Countries: Research Methodology

The econometric methods investigating the interdependence of stock markets have been developed rapidly during the past two decades. The short-run relationship among the Baltic stock markets was explored by applying (a) the Spearman's correlation coefficient, (b) the dynamic conditional correlation generalized autoregressive conditional heteroskedasticity (DCC-GARCH) model, (c) the Granger causality test, and (d) the generalized impulse response (GIR) analysis.

In order to measure the strength of a monotonic relationship between logarithmic returns of the Baltic stock exchange indices, the Spearman's correlation coefficient was applied (1):

$$
\rho=1-\frac{6 \sum_{i=1}^{n}\left(R\left(\Delta \ln x_{i}\right)-R\left(\Delta \ln y_{i}\right)\right)^{2}}{n\left(n^{2}-1\right)},
$$

where $R\left(\Delta \ln x_{i}\right), R\left(\Delta \ln y_{i}\right)$ - the ranks of a pair of logarithmic returns of the Baltic stock exchange indices each containing $n$ observations.

The DCC-GARCH (p, q) model introduced by Engle (2002) is an econometric tool used to model correlation between two or more data series. The standard DCC-GARCH $(1,1)$ model was applied in this empirical study (see Engle, 2009, Nakatani \& Teräsvirta, 2009). The estimation of a GARCH $(1,1)$ model is an intermediate step in order to derive inputs for the DCC-GARCH $(1,1)$ model that was used to model correlation between two particular Baltic stock market indices. In this case, we have three Baltic stock market indices and the return vector is a column vector $\varepsilon_{t}=\left(\varepsilon_{1 t}, \varepsilon_{2 t}, \varepsilon_{3 t}\right)^{\prime}$ with assumptions $\varepsilon_{t} \mid F_{t-1} \sim$ $\mathrm{N}\left(0, H_{t}\right)$. That is, $E\left|\varepsilon_{t}\right| F_{t-1} \mid=0$ and $E\left|\varepsilon_{t}^{\prime} \varepsilon_{t}\right| F_{t-1} \mid=D_{t} P_{t} D_{t}=H_{t}$. Nakatani \& Teräsvirta (2009), Engle (2009) define DCC-GARCH $(1,1)$ model as follows:

$$
\begin{aligned}
& Y_{t}=\mu_{t}+\varepsilon_{t}, \\
& \varepsilon_{t}=D_{t} z_{t},
\end{aligned}
$$

where $Y_{t}$ - three-dimensional vector of logarithmic returns of the Baltic stock exchange indices at time $t$; $\mu_{t}$-three-dimensional vector of the expected value of the conditional $Y_{t}\left(\mu_{t}=E\left(Y_{t} \mid F_{t-1}\right)\right)$;

$\varepsilon_{t}-$ three-dimensional vector of mean-corrected logarithmic returns of the Baltic stock exchange indices at time $t$; 
$D_{t}=\operatorname{diag}\left\{\sqrt{h_{1 t}}, \sqrt{h_{2 t}}, \sqrt{h_{3 t}}\right\}$, and $\sqrt{h_{i t}}$ is the conditional standard deviation of $\varepsilon_{i t}$. The conditional variance follows a univariate GARCH process:

$h_{i t}=\dot{a}_{i 0}+\sum_{j=1}^{q} \dot{a}_{j} a_{i, t-j}^{2}+\sum_{j=1}^{p} \hat{a}_{j} h_{i, t-j}$;

$z_{t}$ - three-dimensional vector of iid errors with $E\left|z_{t}\right| F_{t-1} \mid=$ 0 and $E\left|z_{t}^{\prime} z_{t}\right| F_{t-1}\left|=P_{t}=\right| \rho_{i j, t} \mid$, where $F_{t-1}$ is the information set up to and including time $t-1$;

$H_{t}$ - time-varying conditional covariance matrix of the process $\varepsilon_{t}\left(\left[H_{t}\right]_{i j}=h_{i t} h_{j t} p_{i j, t} i \neq j\right.$, where $\left.1 \leq i, j \leq n\right)$;

$P_{t}$ - time-varying positive definite conditional correlation matrix of the process $\varepsilon_{t} \cdot p_{i j, t}=E\left|z_{i t} z_{j t}\right| F_{t-1} \mid=$

$$
\begin{aligned}
& =\frac{E\left[z_{i t} z_{j t} \mid F_{t-1}\right]}{E\left[z_{i t}^{2} \mid F_{t-1}\right] E\left[z_{j t}^{2} \mid F_{t-1}\right]}=\frac{E\left[\varepsilon_{i t} \varepsilon_{j t} \mid F_{t-1}\right]}{E\left[\varepsilon_{i t}^{2} \mid F_{t-1}\right] E\left[\varepsilon_{j t}^{2} \mid F_{t-1}\right]}= \\
& =\operatorname{corr}\left[\varepsilon_{i t}, \varepsilon_{j t} \mid F_{t-1}\right] .
\end{aligned}
$$

The short-run relationship among the Baltic stock markets was also explored by applying the Granger causality test (Granger, 1969 ) in order to test whether lagged information on variable $x$ provided any statistically significant information about variable $y$ in the presence of lagged variable $y$ and vice versa (4-5):

$$
\begin{aligned}
& y_{t}=\alpha_{0}+\sum_{i=1}^{n} \alpha_{i} y_{t-1}+\sum_{i=1}^{n} \beta_{i} x_{t-1}+\varepsilon_{1 t}, \varepsilon_{1 t} \sim W N\left(0, \sigma^{2}\right), \\
& x_{t}=\delta_{0}+\sum_{i=1}^{n} \delta_{i} x_{t-1}+\sum_{i=1}^{n} \lambda_{i} y_{t-1}+\varepsilon_{2 t}, \varepsilon_{2 t} \sim W N\left(0, \sigma^{2}\right),
\end{aligned}
$$

where $y_{t}, x_{t}$-the logarithmic returns of the Baltic stock exchange indices at time $t$.

The short-run interdependence among the Baltic stock markets was investigated by applying the generalized impulse response analysis (Koop et al., 1996, Pesaran \& Shin, 1998). Impulse response functions show the reaction of one variable to the shocks on other variables in a VAR system (6-7). The main advantage of the generalized approach is that this approach is invariant to the ordering of the variables in the VAR system compared to the traditional impulse response analysis that provides different empirical results depending on the variable ordering.

$$
\begin{aligned}
& Y_{t}=A_{1} Y_{t-1}+\ldots+A_{p} Y_{t-p}+U_{t}=\Phi(B) U_{t}=\sum_{i=0}^{\infty} \Phi_{i} U_{t-i}, \\
& \Phi_{i}=A_{1} \Phi_{i-1}+A_{2} \Phi_{t-2}+\ldots+A_{p} \Phi_{t-p},
\end{aligned}
$$

where $Y_{t}$-three-dimensional vector of the Baltic stock exchange indices;

$\Phi_{i}-$ the coefficients measuring the impulse response, e.g. $\Phi_{j k, i}$ represents the response of stock market index $j$ to a positive shock of one standard deviation in stock market index $k$ occurred $i$-th period ago.

The long-run relationship among the Baltic stock markets was explored by (a) testing for cointegration among the Baltic stock market indices, and applying (b) the autoregressive distributed lag (ARDL) model, and (c) the error correction model (ECM).
Engle \& Granger (1987) state that a linear combination of non-stationary time series may be stationary suggesting that the non-stationary time series are cointegrated. The stationary linear combination of two or more time series may be interpreted as a long-run equilibrium relationship among two or more variables. To test for cointegration among the Baltic stock market indices, the Johansen cointegration test that was proposed by Johansen (1988) was applied to determine how many common cointegrating vectorsthere were across the Baltic stock indices. The identification of the number of cointegration vectors was undertaken simultaneously to estimation (by maximum likelihood) of the short run dynamics between the Baltic stock indices.

In order to test the long-run relationship among the Baltic stock markets, the autoregressive distributed lag model was applied. The ARDL model estimates long-term equilibrium relationships between two time series and short- and long-term effects of independent variables on the dependent variable (8):

$$
\begin{aligned}
& \Delta \ln y_{t}=\alpha+\beta_{0} \Delta \ln y_{t-1}+\sum_{n=0}^{5} \delta_{n} \Delta \ln x_{1, t-n}+ \\
& +\sum_{n=0}^{5} \lambda_{n} \Delta \ln x_{2, t-n}+\varepsilon_{t}, \varepsilon_{t} \sim W N\left(0, \sigma^{2}\right)
\end{aligned}
$$

where $\Delta \ln y_{t}, \Delta \ln x_{1, t}, \Delta \ln x_{2, t}$ - the logarithmic returns of the Baltic stock exchange indices at time $t$.

The estimates of coefficients $\alpha, \beta_{0}, \delta_{n}$, and $\lambda_{n}$ were made using the ordinary least squares (OLS) method. Coefficients $\delta_{0}$ and $\lambda_{0}$ indicate the short-term effect of two particular Baltic stock market indices on the third index and sum of $\delta_{n}$ and $\lambda_{n}$ shows the long-term effect.

The error correction model estimates both short-term and long-term effects of two particular Baltic stock market indices on the third one (9):

$$
\begin{aligned}
& \Delta y_{t}=\alpha+\beta_{0} \Delta x_{1, t} \beta_{1} \Delta x_{2, t}-\beta_{2}\left(y_{t-1}-\beta_{3} x_{1, t-1}-\beta_{4} x_{2, t-1}+\varepsilon_{t}\right), \\
& \varepsilon_{t} \sim W N\left(0, \sigma^{2}\right)
\end{aligned}
$$

where $y_{t}, x_{1, t}, x_{2, t}$ - the Baltic stock exchange indices at time $t$.

The coefficients $\alpha$ and $\beta_{n}$ were estimated using the ordinary least squares method.

Data. Empirical research focuses on the daily data for three main indices of the Baltic stock exchanges: OMX Vilnius (OMXV), OMX Riga (OMXR), and OMX Tallinn (OMXT). The choice of sample countries (Lithuania, Latvia and Estonia) is based on both geography and cooperation levels. The empirical research was performed using daily the first difference of the natural logarithms of the Baltic stock market indices. Daily data on the Baltic stock market indices were obtained from Thomson Financial (Datastream) for a 14-year period, i.e. from January 2000 to June 2014 (atotal number of observations is 3781).

\section{Investigation of Stock Market Integration in the Baltic Countries: Research Results}

The short-run interdependence among the Baltic stock markets is more relevant for financial market participants looking for diversification opportunities. The investigation of the short-run 
interdependence focuses on the analysis of the speed of shock transmission from stock market in one country to another one. In other words, the short-run interdependence indicates the degree of responsiveness and efficiency of stock markets and the speed of new information transmission between different stock markets. The scientific question is whether the increased technical integration of Baltic and Nordic stock markets has increased co-movements of these stock markets.

The results of correlation (Spearman's correlation) analysis suggest a positive statistically significant weak monotonic relationship between logarithmic returns of Tallinn and Vilnius stock exchange indices (see Table I). The interdependence between Latvian and other Baltic stock markets is very weak while a positive statistically significant very weak monotonic relationship between logarithmic returns of these stock markets was identified. These empirical results suggest that the Lithuanian and Estonian stock markets are more integrated at the regional level than the Latvian stock market.

TABLE I

The Results of Correlation Analysis (P-Value in Parentheses)

\begin{tabular}{|c|c|c|c|}
\hline & $\Delta \operatorname{lnOMXR}$ & $\Delta \operatorname{InOMXT}$ & $\Delta \operatorname{lnOMXV}$ \\
\hline$\Delta \operatorname{lnOMXR}$ & $\begin{array}{c}1.000000 \\
(-)\end{array}$ & & \\
\hline \multirow{2}{*}{$\Delta \operatorname{lnOMXT}$} & $\begin{array}{c}0.152368 \\
(0.0000)\end{array}$ & $\begin{array}{c}1.000000 \\
(-)\end{array}$ & \\
\hline \multirow{2}{*}{$\Delta \operatorname{lnOMXV}$} & $\begin{array}{c}0.166327 \\
(0.0000)\end{array}$ & $\begin{array}{c}0.337281 \\
(0.0000)\end{array}$ & $\begin{array}{c}1.000000 \\
(-)\end{array}$ \\
\hline
\end{tabular}

Source: [the author's calculation]
In order to test for unit root behaviour in the first differences of the logarithms of the Baltic stock market indices, the traditional augmented Dickey-Fuller (ADF) test was implemented. The results of ADF test show that all time series data are stationary in their first differences.

The results of dynamic conditional correlation analysis using DCC-GARCH $(1,1)$ model are presented in Fig. 1. The empirical results suggest that dynamic conditional correlation among the logarithmic returns of three Baltic stock market indices is very unstable and time-varying. However, the most significant dynamic conditional correlation was observed between logarithmic returns of OMXV and OMXT ranging between +0.8615 and -0.3033 during the period under analysis.

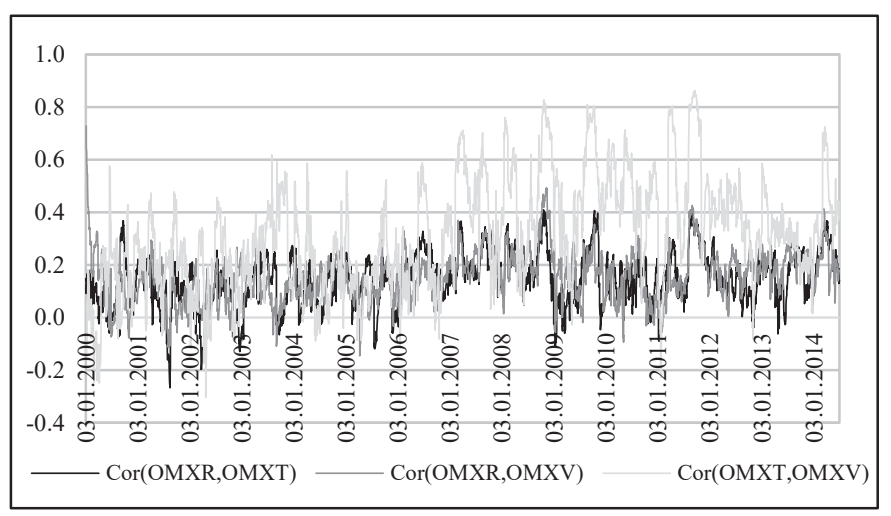

Fig. 1. Dynamic conditional correlation using DCC-GARCH $(1,1)$ model (the author's calculation).

TABLE II

The Results of Pairwise Granger Causality Tests

\begin{tabular}{|c|c|c|c|c|c|c|c|c|c|}
\hline & \multicolumn{3}{|c|}{ OMXR and OMXT } & \multicolumn{3}{|c|}{ OMXR and OMXV } & \multicolumn{3}{|c|}{ OMXV and OMXT } \\
\hline $\begin{array}{l}\text { Number } \\
\text { of lags } \\
\text { included }\end{array}$ & Null hypothesis & F-Statistic & Prob. & Null hypothesis & F-Statistic & Prob. & Null hypothesis & F-Statistic & Prob. \\
\hline \multirow{2}{*}{ Lags: 1} & $\begin{array}{l}\text { OMXT does not } \\
\text { Granger cause OMXR }\end{array}$ & 20.2405 & 0.0000 & $\begin{array}{l}\text { OMXV does not Granger } \\
\text { cause OMXR }\end{array}$ & 25.8306 & 0.0000 & $\begin{array}{l}\text { OMXV does not Grang- } \\
\text { er cause OMXT }\end{array}$ & 3.1245 & 0.0772 \\
\hline & $\begin{array}{l}\text { OMXR does not } \\
\text { Granger cause OMXT }\end{array}$ & 0.1047 & 0.7463 & $\begin{array}{l}\text { OMXR does not Granger } \\
\text { cause OMXV }\end{array}$ & 0.2403 & 0.6240 & $\begin{array}{l}\text { OMXT does not Grang- } \\
\text { er cause OMXV }\end{array}$ & 25.8624 & 0.0000 \\
\hline \multirow{2}{*}{ Lags: 2} & $\begin{array}{l}\text { OMXT does not } \\
\text { Granger cause OMXR }\end{array}$ & 9.7481 & 0.0001 & $\begin{array}{l}\text { OMXV does not Granger } \\
\text { cause OMXR }\end{array}$ & 12.8632 & 0.0000 & $\begin{array}{l}\text { OMXV does not Grang- } \\
\text { er cause OMXT }\end{array}$ & 1.8971 & 0.1501 \\
\hline & $\begin{array}{l}\text { OMXR does not } \\
\text { Granger cause OMXT }\end{array}$ & 0.3785 & 0.6849 & $\begin{array}{l}\text { OMXR does not Granger } \\
\text { cause OMXV }\end{array}$ & 0.4689 & 0.6257 & $\begin{array}{l}\text { OMXT does not Grang- } \\
\text { er cause OMXV }\end{array}$ & 14.5885 & 0.0000 \\
\hline \multirow{2}{*}{ Lags: 3} & $\begin{array}{l}\text { OMXT does not } \\
\text { Granger Cause OMXR }\end{array}$ & 6.4365 & 0.0002 & $\begin{array}{l}\text { OMXV does not Granger } \\
\text { cause OMXR }\end{array}$ & 8.9463 & 0.0000 & $\begin{array}{l}\text { OMXV does not Grang- } \\
\text { er cause OMXT }\end{array}$ & 2.8508 & 0.0360 \\
\hline & $\begin{array}{l}\text { OMXR does not } \\
\text { Granger cause OMXT }\end{array}$ & 1.4968 & 0.2133 & $\begin{array}{l}\text { OMXR does not Granger } \\
\text { cause OMXV }\end{array}$ & 0.5000 & 0.6823 & $\begin{array}{l}\text { OMXT does not Grang- } \\
\text { er cause OMXV }\end{array}$ & 13.2117 & 0.0000 \\
\hline \multirow{2}{*}{ Lags: 4} & $\begin{array}{l}\text { OMXT does not } \\
\text { Granger cause OMXR }\end{array}$ & 5.5853 & 0.0002 & $\begin{array}{l}\text { OMXV does not Granger } \\
\text { cause OMXR }\end{array}$ & 8.4362 & 0.0000 & $\begin{array}{l}\text { OMXV does not Grang- } \\
\text { er cause OMXT }\end{array}$ & 3.8741 & 0.0038 \\
\hline & $\begin{array}{l}\text { OMXR does not } \\
\text { Granger cause OMXT }\end{array}$ & 1.6149 & 0.1676 & $\begin{array}{l}\text { OMXR does not Granger } \\
\text { cause OMXV }\end{array}$ & 0.7673 & 0.5464 & $\begin{array}{l}\text { OMXT does not Grang- } \\
\text { er cause OMXV }\end{array}$ & 9.7535 & 0.0000 \\
\hline \multirow{2}{*}{ Lags: 5} & $\begin{array}{l}\text { OMXT does not } \\
\text { Granger cause OMXR }\end{array}$ & 5.5067 & 0.0001 & $\begin{array}{l}\text { OMXV does not Granger } \\
\text { cause OMXR }\end{array}$ & 7.8028 & 0.0000 & $\begin{array}{l}\text { OMXV does not Grang- } \\
\text { er cause OMXT }\end{array}$ & 3.0380 & 0.0097 \\
\hline & $\begin{array}{l}\text { OMXR does not } \\
\text { Granger cause OMXT }\end{array}$ & 1.2389 & 0.2880 & $\begin{array}{l}\text { OMXR does not Granger } \\
\text { cause OMXV }\end{array}$ & 0.6803 & 0.6384 & $\begin{array}{l}\text { OMXT does not Grang- } \\
\text { er cause OMXV }\end{array}$ & 8.0238 & 0.0000 \\
\hline
\end{tabular}

Notes: The cases of null hypothesis rejection at $10 \%$ significance level are darkened.

Source: [the author's calculation] 
The short-run interdependence between the Baltic stock markets was analysed by testing for Granger causality. The results of Granger causality test using a different number of lags are presented in Table II. The empirical results suggest that OMXT and OMXV do Granger cause OMXR but not vice versa. The results of this study also indicate that bidirectional Granger causality and feedback effect between the Lithuanian and Estonian stock markets exist. The results presented in Table II show that the Lithuanian and Estonian stock indices were most often a significant predictor of other Baltic stock market indices in the period under analysis. Overall, the Granger causality analysis suggests that the Baltic stock markets are interrelated.

The generalized impulse response analysis was applied in order to analyse the short-run interdependence of the Baltic stock indices. The GIR functions representing the reaction of one index to a shock in another are obtained for all Baltic stock market indices. The results of GIR analysis are presented in Fig. 2. Based on the results presented in Fig. 2, two main findings can be formulated. Firstly, the GIR functions show short-lasting effects of external shocks on stock indices lasting only for 3-4 days. Secondly, despite the short-lasting effects, responses of all Baltic stock markets are very small in scale. Figure 2 indicates that the Lithuanian and Estonian stock markets respond to a great extent to changes in the Estonian and Lithuanian stock markets, respectively (excluding these stock markets themselves), peaking in the first day with a response value of around $0.50 \%$.

The reaction of Latvian stock market to shocks in other two Baltic stock markets is least significant and vice versa. Despite insignificant short-term reaction of the Baltic stock markets to changes in other markets, these responses accumulate over the long-run. The responses of the three Baltic stock markets become cumulative significant after 3-4 days: accumulated response of OMXR to shocks in OMXT and OMXV reaches $0.50 \%$ after the fifth day, whereas accumulated response of OMXT and OMXV to shocks in OMXV and OMXT reaches about $0.70 \%$ after the fifth day, respectively. The reaction of the Lithuanian and Estonian stock markets to shocks in the Latvian stock market reaches only about $0.30 \%$ after the fifth day.

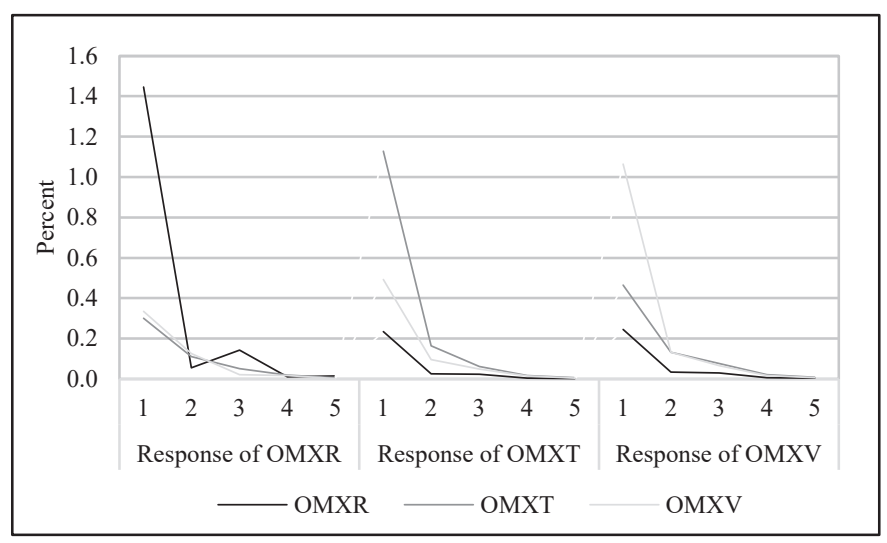

Fig. 2. Response of the Baltic stock indices to generalized one S. D. innovations (the author's calculation).

The results of generalized impulse response analysis confirm that the Lithuanian and Estonian stock markets are more interre- lated whereas the Latvian stock market is less sensitive to shocks in other two Baltic stock markets.

The long-run relationship among the Baltic stock markets was explored by testing for cointegration among the Baltic stock market indices. The results of the Johansen cointegration test are reported in Table III.

TABLE III

The Results of the Johansen Cointegration Test

\begin{tabular}{|l|c|c|c|c|}
\hline \multicolumn{5}{|c|}{ Unrestricted Cointegration Rank Test (Trace) } \\
\hline $\begin{array}{c}\text { Hypothesized } \\
\text { No. of CE(s) }\end{array}$ & Eigenvalue & $\begin{array}{c}\text { Trace } \\
\text { statistic }\end{array}$ & $\begin{array}{c}0.05 \text { critical } \\
\text { value }\end{array}$ & Prob.** \\
\hline None * & 0.0072 & 46.0905 & 35.0109 & 0.0023 \\
\hline At most 1 * & 0.0043 & 18.7625 & 18.3977 & 0.0445 \\
\hline At most 2 & 0.0007 & 2.6620 & 3.8415 & 0.1028 \\
\hline \multicolumn{5}{|c|}{ Unrestricted Cointegration Rank Test (Maximum Eigenvalue) } \\
\hline $\begin{array}{c}\text { Hypothesized } \\
\text { No. of CE(s) }\end{array}$ & Eigenvalue & $\begin{array}{c}\text { Max-Eigen } \\
\text { statistic }\end{array}$ & $\begin{array}{c}0.05 \text { critical } \\
\text { value }\end{array}$ & Prob.** \\
\hline None * & 0.0072 & 27.3280 & 24.2520 & 0.0190 \\
\hline At most 1 & 0.0043 & 16.1005 & 17.1477 & 0.0705 \\
\hline At most 2 & 0.0007 & 2.6620 & 3.8415 & 0.1028 \\
\hline
\end{tabular}

Notes: trend assumption - quadratic deterministic trend, lag interval (in first differences) -1 to $2 .{ }^{*}$ denotes rejection of the hypothesis at the 0.05 level. ** MacKinnon-Haug-Michelis (1999) $p$-values.

Source: [the author's calculation]

This table gives Johansen trace and maximum eigenvalue statistics assuming an intercept and quadratic deterministic trend in the cointegrating relationship. Trace test indicates 2 cointegrating equations statistically significant at the 0.05 level and the maximum eigenvalue test indicates 1 cointegrating equation statistically significant at the 0.05 level. The empirical results suggest that there is the long-run relationship among the Baltic stock markets.

The results of long-run and short-run relationship among the Baltic stock markets using the ARDL models are reported in Table IV.

While the residuals of the estimated equations are serially correlated and conditionally heteroskedastic, the HAC method proposed by Newey $\&$ West (1987) was used. The short-run elasticities $\delta_{0}$ and $\lambda_{0}$ of the Baltic stock market indices are relatively high. These results indicate a positive and statistically significant short-run effect of the changes in the analysed stock markets on trends in other Baltic stock markets. However, the long-run elasticities among the Baltic stock markets are close to zero and statistically insignificant in most cases. The empirical results suggest substantial evidence of simultaneous short-term effects on returns in all three Baltic stock markets. In terms of returns, Riga is dependent on the indices of Tallinn and Vilnius (the effect of Tallinn is short-term and weak compared to the effect of Vilnius), Tallinn is dependent on Vilnius and Riga (the effect of Riga is very weak and only short-term compared to a more stronger effect of Vilnius) and Vilnius - on Tallinn and Riga (the effect of Tallinn is both short- and long-run). The empirical results show that the effect of the Latvian stock market on the Lithuanian and Estonian stock markets is short-run and very weak compared to short-run and long-run relationship between the Lithuanian and Estonian stock markets. 
TABLE IV

Parameter Estimates of the ARDL Models (P-Values in Parentheses)

\begin{tabular}{|c|c|c|c|}
\hline & $\begin{array}{c}\text { Model I } \\
\text { Dependent vari- } \\
\text { able } \Delta \text { InOMXR }\end{array}$ & $\begin{array}{c}\text { Model II } \\
\text { Dependent vari- } \\
\text { able } \Delta \ln O M X T\end{array}$ & $\begin{array}{c}\text { Model III } \\
\text { Dependent vari- } \\
\text { able } \Delta \operatorname{lnOMXV}\end{array}$ \\
\hline$\alpha$ & $0.0152(0.5227)$ & $0.0188(0.2506)$ & $0.0110(0.4924)$ \\
\hline$\beta_{0}$ & $0.0196(0.7486)$ & $0.0905(0.0005)$ & $0.0650(0.0159)$ \\
\hline$\delta_{0}$ & $0.1666(0.0000)$ & $0.0878(0.0000)$ & $0.1101(0.0003)$ \\
\hline$\delta_{1}$ & $0.0129(0.6696)$ & $-0.0094(0.5455)$ & $-0.0015(0.9211)$ \\
\hline$\delta_{2}$ & $0.0211(0.4011)$ & $-0.0074(0.6012)$ & $-0.0073(0.5321)$ \\
\hline$\delta_{3}$ & $-0.0162(0.4859)$ & $0.0130(0.3442)$ & $-0.0054(0.6548)$ \\
\hline$\delta_{4}$ & $-0.0099(0.7544)$ & $0.0144(0.2456)$ & $0.0216(0.1136)$ \\
\hline$\delta_{5}$ & $0.0154(0.5644)$ & $0.0040(0.7492)$ & $0.0053(0.7107)$ \\
\hline$\sum_{n=0}^{5} \delta_{n}$ & 0.1666 & 0.0878 & 0.1101 \\
\hline$\lambda_{0}$ & $0.2382(0.0000)$ & $0.4332(0.0000)$ & $0.3820(0.0000)$ \\
\hline$\lambda_{1}$ & $0.0610(0.0328)$ & $-0.0154(0.5368)$ & $0.0231(0.3852)$ \\
\hline$\lambda_{2}$ & $-0.0244(0.4173)$ & $0.0092(0.6189)$ & $0.0260(0.1483)$ \\
\hline$\lambda_{3}$ & $0.0237(0.3546)$ & $0.0175(0.2850)$ & $0.0540(0.0005)$ \\
\hline$\lambda_{4}$ & $0.0046(0.8811)$ & $0.0299(0.0853)$ & $-0.0074(0.7220)$ \\
\hline$\lambda_{5}$ & $0.0181(0.4869)$ & $0.0168(0.2705)$ & $-0.0011(0.9439)$ \\
\hline$\sum_{n=0}^{5} \lambda_{n}$ & 0.2992 & 0.4631 & 0.4360 \\
\hline Adj. $R^{2}$ & 0.0749 & 0.2229 & 0.2347 \\
\hline$\hat{\sigma}$ & 1.4041 & 1.0052 & 0.9432 \\
\hline $\mathrm{JB}$ & $36796.32(0.00)$ & $3682.08(0.00)$ & $35450.07(0.00)$ \\
\hline $\mathrm{LM}(1)$ & $13.23(0.00)$ & $0.43(0.51)$ & $2.01(0.15)$ \\
\hline $\mathrm{LM}(5)$ & $13.23(0.00)$ & $0.99(0.42)$ & $2.26(0.05)$ \\
\hline $\mathrm{BPG}$ & $3.57(0.00)$ & $1.46(0.13)$ & $5.77(0.00)$ \\
\hline
\end{tabular}

Notes: Adj. $\mathrm{R}^{2}$ - adjusted coefficient of determination; $\hat{\sigma}-$ standard error of regression; JB - Jarque-Bera normality test; LM(n) - Breusch-Godfrey Lagrange multiplier test for autocorrelation up to order $n$; BPG - Breusch-Pagan-Godfrey test for heteroskedasticity. The cases of null hypothesis rejection at $10 \%$ significance level are darkened. The specification of the ARDL models: model I $\left(\Delta \ln x_{1}=\Delta \operatorname{lnOMXT}, \Delta \ln x_{2}=\Delta \operatorname{lnOMXV}\right)$, model II $\left(\Delta \ln x_{1}=\Delta \operatorname{lnOMXR}, \Delta \ln x_{2}=\right.$ $\Delta \operatorname{lnOMXV})$, and model III $\left(\Delta \ln x_{1}=\Delta \operatorname{lnOMXR}, \Delta \ln x_{1}=\Delta \operatorname{lnOMXT}\right)$

Source: [the author's calculation]

The estimates of both long-term and short-term effects of two particular Baltic stock market indices on the third one were evaluated using the error correction model. However, the goodness of fit parameters of the estimated equations was very low: adjusted coefficient of determination ranged from 1.5 to $2.5 \%$, standard error of regression - from 5 to 6 , the residuals of the estimated equations were serially correlated, conditionally heteroskedastic, and not normally distributed, etc. Thus, the interpretation of estimates of regression equations could be misleading and incorrect.

To sum up, the empirical results of this study provide support for the simultaneity in returns in all three Baltic stock markets. The Baltic stock markets are located in the same geographic region and closely related due to their institutional structure, common large traders, common trading platform and single trading and clearing currency (euro) since 2010, etc. Despite the fact that all three Baltic stock markets are closely related markets, there are some differences. The Latvian stock market is more isolated at the regional level compared to other two Baltic stock markets, whereas the Estonian and Lithuanian stock markets are more interrelated. There are some explanations for higher
Lithuanian and Estonian stock market interdependence. Firstly, the residents of Lithuania are the main non-resident holders of equity securities (portfolio investment) issued by Estonian residents and vice versa. According to the International Monetary Fund results from its Coordinated Portfolio Investment Survey for end - December 2013, the residents of Lithuania hold about $20 \%$ of equity securities (portfolio investment) issued by Estonian residents and Estonian residents hold even 37 percent of equity securities (portfolio investment) issued by Lithuanian residents. Thus, the decisions of common traders and investors in one stock market could influence the investment decisions of the same traders and investors in the other stock market. Secondly, a majority of stocks listed on the Baltic main list are stocks of Lithuanian and Estonian companies, which are more attractive to foreign investors and traders due the higher liquidity of those stocks. According to NASDAQ OMX data, on the Baltic main list there are listed 16 Lithuanian companies, 13 Estonian companies and only 5 Latvian companies at the end of September 2014, whereas the Baltic secondary list consists mainly of Latvian companies.

\section{CONCLusion}

The research on stock market integration in the Baltic countries allows formulating the following conclusions:

1. The empirical results suggest a weak and positive monotonic relationship between the logarithmic returns of the Estonian and Lithuanian stock exchange indices, whereas a positive and very weak monotonic relationship between logarithmic returns of Latvian and other stock market indices has been identified. The empirical results show that dynamic conditional correlation among the logarithmic returns of three Baltic stock market indices is very unstable and time-varying. The empirical results suggest that the changes in Tallinn and Vilnius stock exchanges do Granger cause the changes in Riga stock exchange but not vice versa. The results of this study also indicate that a bidirectional Granger causality and feedback effect between the Lithuanian and Estonian stock markets exist.

2. The Lithuanian and Estonian stock markets respond most strongly to changes in the Estonian and Lithuanian stock markets, respectively (excluding these stock markets themselves). The reaction of the Latvian stock market to shocks in other two Baltic stock markets is least significant and vice versa. Despite the insignificant short-run reaction of the Baltic stock markets to changes in other markets, these responses accumulate over the long-run. The responses of the three Baltic stock markets become cumulative significant after 3-4 days. The results of generalized impulse response analysis confirm that the Lithuanian and Estonian stock markets are more interrelated, whereas the Latvian stock market is less sensitive to shocks in other two Baltic stock markets.

3. The results of the Johansen cointegration test suggest that there is the long-run relationship among the Baltic stock markets. The empirical results indicate a positive and statistically significant short-run effect of the changes in the 
analysed stock markets on trends in other Baltic stock markets. The empirical results suggest strong evidence of simultaneous short-term effects on returns in all three Baltic stock markets. The results show that the effect of the Latvian stock market on the Lithuanian and Estonian stock markets is short-run and very weak compared to short-run and long-run relationship between the Lithuanian and Estonian stock markets.

4. The empirical results of this study provide support for the simultaneity in returns in all three Baltic stock markets. The Baltic stock markets are located in the same geographic region and closely related due to their institutional structure, common large traders, common trading platform and single trading and clearing currency (euro) since 2010, etc. Despite the fact that all three Baltic stock markets are closely related markets, there are some differences. The Latvian stock market is more isolated at the regional level compared to the other two Baltic stock markets, whereas the Estonian and Lithuanian stock markets are more interrelated.

5. This empirical study has investigated the integration of the Baltic stock markets in terms of logarithmic returns; however, there are some suggestions and recommendations for the future research in this field. The integration of the Baltic stock markets should also be analysed in terms of stock market volatilities, while some empirical studies suggest that the interdependence among stock market volatilities is more significant. The integration of the Baltic stock markets should also be analysed at the global level.

\section{Discussion}

The research results of this empirical study raise some questions for discussion. Despite the fact that all three Baltic stock markets are closely related markets, can a stronger Estonian and Lithuanian stock market interdependence be explained by common large traders or are there some other explanations for this fact? Can a higher technical integration of the Nordic and Baltic stock markets imply higher stock market integration in terms of returns and volatilities in these countries? Which drivers could foster the higher development and liquidity level of the Baltic stock markets? Which factors could increase a higher degree of the Baltic stock market international integration in the next decade? These and many other questions could be answered in future empirical studies exploring the Baltic stock markets.

\section{ACKNOWLEDGMENT}

This research has been funded by a grant (No. MIP-016/2015) from the Research Council of Lithuania.

\section{REFERENCES}

Brännäs, K \& Soultanaeva, A. (2011). Influence of News from Moscow and New York on Returns and Risks of Baltic States' Stock Markets. Baltic Journal of Economics, 11(1), 109-124. http://dx.doi.org/10.1080/140609 9X.2011.10840493
Brännäs, K., De Gooijer, J. G., Lönnbark, C.\& Soultanaeva, A. (2012). Simultaneity and Asymmetry of Returns and Volatilities: The Emerging Baltic States' Stock Exchanges. Studies in Nonlinear Dynamics \& Econometrics, 16(1), 1-24. http://dx.doi.org/10.1515/1558-3708.1855

Cajueiro, D. O.\& Tabak, B. M. (2006). Testing for Predictability in Equity Returns for European Transition Markets. Economic Systems, 30, 56-78. http:// dx.doi.org/10.1016/j.ecosys.2005.09.003

Dubinskas, P. \& Stunguriené, S. (2010). Alterations in the Financial Markets of the Baltic Countries and Russia in the Period of Economic Downturn. Technological and Economic Development of Economy, 16(3), 502-515. http:// dx.doi.org/10.3846/tede.2010.31

Engle, R. (2002). Dynamic Conditional Correlation: A Simple Class of Multivariate Generalized Autoregressive Conditional Heteroskedasticity Models. Journal of Business and Economic Statistics, 20(3), 339-350. http://dx.doi. org/10.1198/073500102288618487

Engle, R. (2009). Anticipating Correlations: A New Paradigm for Risk Management. Princeton: Princeton University Press.

Engle, R. F. \& Granger, C. W. J. (1987). Co-integration and Error Correction: Representation, Estimation, and Testing. Econometrica, 55, 251-276. http:// dx.doi.org/10.2307/1913236

Granger, C. W. J. (1969). Investigating Causal Relations by Econometric Methods and Cross-Spectral Methods. Econometrica, 34, 424-438. http://dx.doi. org/10.2307/1912791

Johansen, S. (1988). Statistical Analysis of Cointegrating Vectors. Journal of Economic Dynamics and Control, 12, 231-254. http://dx.doi. org/10.1016/0165-1889(88)90041-3

Koop, G., Pesaran, M. H. \& Potter S. M. (1996). Impulse Response Analysis in Nonlinear Multivariate Models. Journal of Econometrics, 74, 119-147. http://dx.doi.org/10.1016/0304-4076(95)01753-4

Kuusk, A., Paas, T.\& Viikmaa, K. (2011). Financial Contagion of the 2008 Crisis: Is There Any Evidence of Financial Contagion from the US to the Baltic States. Eastern Journal of European Studies, 2(2), 61-76.

Maneschiöld, P. O. (2006). Integration between the Baltic and International Stock Markets. Emerging Markets Finance and Trade, 42(6), 25-45. http:// dx.doi.org/10.2753/REE1540-496X420602

Masood, O., Bellalah, M., Chaudhary, S., Mansour, W. \& Teulon, F. (2010) Cointegration of Baltic Stock Markets in the Financial Tsunami: Empirical Evidence. International Journal of Business, 15(1), 119-132.

Mateus, T. (2004). The Risk and Predictability of Equity Returns of the EU Accession Countries. Emerging Markets Review, 5, 241-266. http://dx.doi. org/10.1016/i.ememar.2004.03.003

Nakatani, T.\& Teräsvirta, T. (2009). Testing for Volatility Interactions in the Constant Conditional Correlation GARCH Model. Econometrics Journal, 12(1), 147-163. http://dx.doi.org/10.1111/j.1368-423X.2008.00261.x

Newey, W. \& West, K. (1987). A Simple Positive Semi-Definite, Heteroskedasticity and Autocorrelation Consistent Covariance Matrix. Econometrica, 55, 703-708. http://dx.doi.org/10.2307/1913610

Nielsson, U. (2007). Interdependence of Nordic and Baltic Stock Markets. Baltic Journal of Economics, 6(2), 2007, 9-27. http://dx.doi.org/10.1080/1406 099X.2007.10840434

Nikkinen, J., Piljak, V.\& Äijö, J. (2012). Baltic Stock Markets and the Financial Crisis of 2008-2009. Research in International Business and Finance, 26, 398-409. http://dx.doi.org/10.1016/j.ribaf.2012.03.003

Pajuste, A., Kepitis, G., \& Högfeldt, P. (2000). Risk Factors and Predictability of Stock Returns in Central and Eastern Europe. Emerging Markets Quarterly, $1-18$.

Pesaran, M. H., \& Shin, Y. (1998). Generalized Impulse Response Analysis in Linear Multivariate Models. Economic Letters, 58, 17-29. http://dx.doi. org/10.1016/S0165-1765(97)00214-0

Soultanaeva, A. (2008). Impact of Political News on the Baltic State Stock Markets. Umeå Economic Studies, 735, 1-21.

Syllignakis, M. N., \& Kouretas, G. P. (2011). Dynamic Correlation Analysis of Financial Contagion: Evidence from the Central and Eastern European Markets. International Review of Economics and Finance, 20, 717-732. http:// dx.doi.org/10.1016/j.iref.2011.01.006

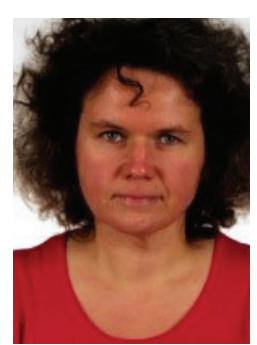

Vilma Deltuvaitè is a Lecturer at the Department of Finance, School of Economics and Business, Kaunas University of Technology, Lithuania. Address: K. Donelaicio Str. 73, LT-44309 Kaunas, Lithuania.

She has experience working as an Accounting and Logistics Specialist, Chief Financial Officer (CFO), Head of Logistics Department, General Manager (CEO) at private enterprises.

She obtained a Doctoral degree in Social Sciences (Management) at Kaunas University of Technology in 2013. Research interests: systemic risk management in banking sector, banking crises, banking sector's financial stability, assessment of banks' profitability and efficiency, cross-border contagion risk.

E-mail address: vilma.deltuvaite@ktu.lt 